\title{
KARAKTERISTIK ANGGOTA DEWAN PERWAKILAN RAKYAT DAERAH SEBAGAI VARIABEL ANTESEDEN TINGKAT KORUPSI DAN IMPLIKASINYA TERHADAP KUALITAS AUDIT (Studi Kasus di Pemerintah Provinsi Banten)
}

\author{
Rudi Zulfikar, Kurniasih Dwi Astuti \\ Jurusan Akuntansi \\ Universitas Sultan Ageng Tirtayasa \\ *Coressponding Author, email : rz-zulfikar72@untirta.ac.id
}

\begin{abstract}
Abstrak
Tujuan penelitian ini untuk mengetahui pengaruh Personal Background, Political Background, pengetahuan dan Pemahaman anggota Dewan Perwakilan Rakyat Daerah Propinsi Banten terhadap tingkat Korupsi serta implikasinya terhadap Kualitas Audit. Populasi penelitian ini adalah seluruh anggota DPRD Provinsi Banten sejumlah 85 orang. Metode analisis data penelitian ini yaitu analisis regresi berganda. Hasil pengujian menunjukkan Personal background, pengetahuan dan Pemahaman anggota Dewan Perwakilan Rakyat Daerah Provinsi Banten berpengaruh menurunkan terhadap tingkat Korupsi. Hasil lainnya, Tingkat Korupsi berpengaruh negatif terhadap Kualitas Audit. Sedangkan Political Background tidak berpengaruh.
\end{abstract}

Kata Kunci: Anggota DPRD, Tingkat Korupsi, Kualitas Audit

Abstract

The purpose of this study was to determine the effect of Personal Background, Political Background, knowledge and understanding of members of the Banten Province Regional Representative Council on the level of Corruption and its implications for Audit Quality. The population of this study was all members of the Banten Province DPRD numbering 85 people. The data analysis method of this research is multiple regression analysis. The test results show that the Personal background, knowledge and understanding of the members of the Regional Representatives Council of Banten Province has the effect of reducing the level of Corruption. Other results, the level of corruption has a negative effect on audit quality. While the Political Background has no effect.

Keywords: DPRD Members, Corruption Level, Audit Quality 
Jurnal Administrasi Negara

ISSN : 2598-4039 (Online)

ISSN : 2302-2231 (Print)

\section{Rudi Zulfikar, Kurniasih Dwi Astuti Jurusan Akuntansi}

Universitas Sultan Ageng Tirtayasa

\section{PENDAHULUAN}

Sejak diberlakukannya Undangundang (UU) Nomor 22 Tahun 1999 tentang Pemerintahan Daerah serta UU Nomor 25 Tahun 1999 tentang Perimbangan Keuangan Antara Pemerintah Pusat dan Daerah (PKPD). Hingga kini, kedua regulasi tersebut sudah mengalami beberapa kali revisi hingga yang terakhir UU Nomor 23 Tahun 2014 tentang Pemerintahan Daerah serta UU Nomor 33 Tahun 2004 tentang Perimbangan Keuangan Antara Pemerintah Pusat dan Pemerintahan Daerah. Perubahan tersebut disesuaikan dengan kondisi pengelolaan pemerintah daerah yang mengalami perkembangan sesuai dengan kebutuhan organisasi. Akan tetapi pelaksanaan pengelolaan keuangan pemerintah tidak sesuai dengan amanah dalam Undang undang tersebut.

Beberapa kasus di Provinsi
Banten yang berkaitan dengan pengelolaan keuangan pemerintah anatara lain 90\% Satuan Kerja Perangkat Daerah (SKPD) di Provinsi Banten terlibat korupsi (www.Liputan6.com 2014), Tahun 2016 dua anggota DPRD Banten akibat suap pengesan APBD tentang pembentukan Bank Pembangunan Daerah atau Bank Banten (News detik.com, 2018), Menurut Lembaga Swadaya Banten Bersih sejak tahun 2014 di Provinsi Banten muncul 6 kasus, Kota Serang 5 kasus, Kabupaten Serang 10 kasus, Kota Tangerang 5 kasus, Tangerang 4 kasus, Cilegon 4 kasus, Pandeglang dan Lebak 7 kasus (News detik.com, 2018).

Beberapa kasus teresebut berkaitan dengan Korupsi yang terjadi di Pemerintah Provinsi Banten. Menurut UU No. 31 tahun 1999 yang kemudian di revisi dengan UU No. 20 tahun 2000 menyebutkan bahwa korupsi adalah Setiap orang yang secara melawan hukum melakukan perbuatan memperkaya diri sendiri atau orang lain atau suatu korporasi yang dapat merugikan keuangan negara atau perekonomian negara. dari pengertian tersebut dapat disimpulkan bahwa korupsi merupakan perbuatan yang dilakukan pribadi maupun kelompok yang merugikan negera.

Korupsi di pemerintahan merupakan gejala kegagalan pemerintahan, hal ini disebabkan oleh kualitas manejemen, akuntabilitas dan transparansi pengelolaan keuangan pemerintah (World Bank, 2006). Menurut survey Tranparancy International (2018), Indonesia menempati rangking 89 dari 180 negara yang di survey. Semakin tinggi rangkingnya maka semakin banyak kasus korupsi yang terjadi di negara tersebut.

Menurut Rose dan Palifka (2016) korupsi terjadi ketika kekayaan pribadi dan kekuasaan menjadi satu kesatuan. Suap mendorong para pengambil keputuan untuk melakukan tindakan mementingkan kepentingannya sehingga bertentangan dengan 
Jurnal Administrasi Negara

ISSN : 2598-4039 (Online)

ISSN : 2302-2231 (Print)

\section{Rudi Zulfikar, Kurniasih Dwi Astuti Jurusan Akuntansi \\ Universitas Sultan Ageng Tirtayasa}

kepentingan publik. Korupsi yang terjadi di pemerintahan salah satunya belum optimalnya fungsi Dewan Perwakilan Rakyat Daerah Sementara itu, menurut UU Nomor 27 Tahun 2009, tentang Majelis Permusyawaratan Rakyat, Dewan Perwakilan Rakyat, Dewan perwakilan Daerah, dan Dewan Perwakilan Rakyat Daerah, DPRD mempunyai tiga fungsi, yaitu fungsi legislasi, fungsi anggaran, dan fungsi pengawasan. Akan tetapi dalam implementasinya fungsi tersebut masih rendah (Winarna dan Murni, 2007). Kurang optimalnya fungsi pengawasan oleh DPRD mengakibatkan terjadinya kebijakan yang lebih mengutamakan kepentingan pribadi, golongan dan partainya (Martin dan Whitaker, 2019).

La Palombara (2015) berpendapat bahwa Institusi Politik, Partai politik, latar belakang, pengalaman serta ideologi yang dapat berpengaruh terhadap sifat dan prilaku anggota DPRD. Indonesia memiliki karakteristik anggota DPRD berbeda dengan negara lain yaitu peran latar belakang, Politik dan Pengalaman mendominasi terpilihnya anggota DPRD periode berikutnya (Prihatini, 2019). Pendapat lainnya didukung oleh Biryukov (2019) dan Rocabert et al. (2019) bahwa di negara Asia anggota DPR yang terpilih kembali selain didasarkan pada kedekatan pimpinan partai akan tetapi latar belakng politik, pengalaman dan pemahaman peraturan merupakan faktor determinan terpilihnya kembali.
Penelitian Norton dan Ahmed (1998) membuktikan bahwa latar belakang dan pengalaman berpengaruh negatif turunnya tingkat korupsi. Penelitian lainnya Ahmed (2001) menyimpulkan bahwa latar belakang Pendidikan dan pemahaman terhadap peraturan dapat mengurangi terjadinya korupsi. Akan tetapi penelitian di Indonesia dilakukan oleh Winarna dan Murni (2001) menyimpulkan bahwa latar belakang personal dan latar belakang politik tidak berpengaruh terhadap pengawasan keuangan daerah. Sementara itu Kartikasari (2012) membuktikan bahwa latar belakang politik dan pengalaman berpengaruh meningkatkan pengawasan sehingga dapat menurunkan tingkat korupsi.

Menurut Malagueño, Albrecht, Ainge, dan Stephens (2010) bahwa Auditor independent memberikan opini Laporan Keuangan pemerintah dengan Wajar Tanpa Pengecualian (Unqualified Opinion) mencerminkan bahwa laporan keuangan tersebut sudah sesuai atau wajar menurut standar yang berlaku. Sementara itu Kassem dan Higson (2016) berpendapat bahwa Laporan Keuangan dengan audit opinion Wajar Tanpa Pengecualian tidak mencerminkan pengelolaan keuangan pemerintah tidak terjadi kesalahan. Hal ini dikarenakan dalam pemeriksaan atas kewajaran laporan keuangan pemerintah di dasarkan pada keterbatasan yang memadai yang didasarkan pada Profesional Judment. 
Jurnal Administrasi Negara

ISSN : 2598-4039 (Online)

ISSN : 2302-2231 (Print)
Rudi Zulfikar, Kurniasih Dwi Astuti Jurusan Akuntansi Universitas Sultan Ageng Tirtayasa
Penelitian Andersson dan Bergman (2009) membuktikan bahwa Korupsi yang terjadi di Pemerintahan dapat mempengaruhi opini auditor. Hasil ini didukung oleh penelitian Rocabert et al. (2019) dan Mauro(1995) bahwa Tingginya tingkat korupsi dapat berpengaruh terhadap kepatuhan peraturan pengelolaan keuangan pemerintah sehingga akan berpengaruh kewajaran atasa laporan keuangan tersebut.

Penelitian ini fokus pada biaya yang dibebankan kepada prinsipal akibat dari adanya konflik tersebut berupa monitoring cost. Monitoring yang dilakukan oleh Dewan Perwakilan Rakyat Daerah (DPRD) diharapkan mampu mengurangi konflik keagenan. Monitoring dapat menjadi solusi konflik kepentingan antara Ekskutif dan DPRD jika dalam kontrak secara jelas (tanpa ambiguitas), diterangkan bahwa DPRD memiliki hak untuk memantau dan membatasi perilaku Eksekutif. Sehingga dapat disimpulkan bahwa penerapan monitoring tersebut didasarkan pada judgement prinsipal mengenai apakah perilaku Ekskutif dapat diubah, serta apakah terdapat ambiguitas dalam kontrak mengenai hak prinsipal melakukan monitoring.

Selanjutnya, mengenai bonding cost Jensen dan Meckling (1976) menjelaskan bahwa dapat menjadi solusi konflik kepentingan antara Eksekutif dan DPRD, apabila DPRD bersedia menanggung biaya bonding tersebut. Dijelaskan pula bahwa DPRD akan bersedia menanggung biaya bonding tersebut apabila berdasarkan perhitungannya, peningkatan bersih dalam kekayaan yang dihasilkan lebih besar daripada konsumsi yang dilepaskannya. Jenis biaya keagenan yang ketiga adalah kerugian residual (residual loss). Kerugian residual merupakan total biaya keagenan yang ditimbulkan karena penjualan ekuitas oleh DPRD yang disebabkan kegiatan monitoring dan bonding tidak berjalan sebagaimana diharapkan. Penurunan kesejahteraan manajer sebagai akibat kerugian residual dengan nilai kepadanya dari peningkatan manfaat non-uang.

$$
\text { Forum For Corporate }
$$

Governance In Indonesia (FCGI) (2000) menyebutkan prinsipal (DPRD) hanya bertugas untuk mengawasi dan memonitor jalannya perusahaan yang dikelola oleh agen (Eksekutif). Agen bertugas menjalankan manajemen perusahaan untuk kepentingan Rakyat dan dijamin memiliki keleluasaan dalam melakukannya. Dalam penelitian ini, teori keagenan menjelaskan pentingnya monitoring yang dilakukan DPRD dalam menekan perilaku oportunis eksekutif. Monitoring dilakukan melalui mekanisme internal oleh DPRD berkaitan dengan akuntabilitas, pengawasan, dan pengendalian manajemen pemerintahan serta berhubungan dengan penggunaan sumber daya dan risiko yang akan 
Jurnal Administrasi Negara

ISSN : 2598-4039 (Online)

ISSN : 2302-2231 (Print)
Rudi Zulfikar, Kurniasih Dwi Astuti Jurusan Akuntansi

Universitas Sultan Ageng Tirtayasa dihadapi (Llewellyn dan Sinha, 2000). Semakin optimal monitoring maka prilaku oportunis manajemen (eksekutif) berkurang, hal ini dikarenakan DPRD mendorong manajemen mengelola pemerintahan patuh terhadap regulasi..

Mekanisme monitoring melalui mekanisme internal di Pemerintah Provinsi Banten memiliki tujuan yaitu untuk memastikan bahwa Eksekutif bertindak sesuai kontrak dan untuk memenuhi kepentingan masyarakat. Monitoring yang optimal menghasilkan suatu governance outcome yaitu berkurangnya konflik kepentingan antar pihak yang berkepentingan. Hasil akhir dari governance outcome akan terealisasi melalui peningkatan kepatuhan pengeleloaan Pemerintah sesuai peraturan yang berlaku.

Peneltian ini merupakan pengembangan penelitian sebelumnya yaitu membuktikan implikasi dari Tingkat Korupsi terhadap Kualitas Audit di Pemerintah Provinsi Banten. Hal ini dapat memberikan pembuktian efek terjadinya korupsi di Pemerintah Provinsi Banten terhadap opni auditor Badan Pemeriksa Keuangan atas Laporan Keuangan. Selain itu, penelitian ini bertujuan untuk menguji pengaruh Karakateristik Anggota Dewan Perwakilan Daerah sebagai variable antesenden Tingkat Korupsi dan Implikasinya terhadap Laporan Auditor Badan Pemeriksa Keuangan.

\section{METODE PENELITIAN}

Populasi dari penelitian ini adalah seluruh anggota DPRD Propinsi Banten dengan menggunakan metode purposive sampling yaitu pemilihan sampel secara tidak acak yang informasinya diperoleh dengan menggunakan pertimbangan tertentu dimana umumnya disesuaikan dengan tujuan atau masalah penelitian. Oleh karena itu, sampel yang dipilih yang dijadikan responden dalam penelitian ini adalah seluruh anggota DPRD periode 2015-2019 seluruh anggota DPRD tersebut melakukan fungsi pengawasan keuangan daerah (APBD) sebesar 85 anggota.

Data dan sumber data yang akan digunakan dalam penelitian ini diperoleh cari catatan dan uraian lengkap dari basis data yang terpercaya baik dari data yang tersedia di media cetak maupun media elektronik. Pengumpulan data dalam penelitian ini menggunakan tekhnik data sekunder dan data Primer. Data sekunder tersebut terdiri dari data berikut ini:
a) Laporan keuangan pemerintah daerah tahun 2015 - 2019
b) Perundang-undangan dan peraturan lain yang terkait dengan kebijakan desentralisasi fiskal, otonomi daerah, korupsi dan kebijakan keuangan yang terkait dengan pemerintah daerah.
c) Jumlah Anggota Dewan Perwakilan Rakyat Daerah Provinsi


Jurnal Administrasi Negara

ISSN : 2598-4039 (Online)

ISSN : 2302-2231 (Print)
Rudi Zulfikar, Kurniasih Dwi Astuti
Jurusan Akuntansi

Universitas Sultan Ageng Tirtayasa
Banten 2015-2019 sebanyak 85 anggota.

Data yang dibutuhkan dalam penelitian tersebut dikumpulkan dari catatan atau basis data baik berupa hardcopy maupun softcopy yang diperoleh dari hasil download pada website dan dokumentasi arsip-arsip Badan Pemeriksa Keuangan Republik Indonesia (BPK RI) dan sumber lain yang terkait.

Data lainya yang diperlukan yaitu jenis data yang digunakan dalam penelitian ini adalah data primer. Data primer merupakan sumber data penelitian yang diperoleh peneliti secara langsung melalui penyampaian kuesioner kepada responden di lingkungan anggota DPRD Propinsi Banten.

Metode pengumpulan data primer dari responden dilakukan dengan survei, yaitu dengan cara mengumpulkan data pokok (data primer) dari suatu sampel dengan menggunakan instrumen kuisioner dengan cara memberikan daftar pernyataan tertulis kepada responden. Setiap paket kuisioner terdiri dari dua bagian yang harus dijawab oleh responden dengan mengikuti perintah yang terdapat didalam setiap bagian. Bagian pertama berisi pernyataan yang berhubungan dengan personal background dan political background dari responden yang meliputi jenis kelamin, pendidikan, jabatan, pengalaman politik, pengalaman di DPRD, latar belakang partai politik, dan lain-lain. Bagian kedua adalah pernyataan yang berhubungan dengan pengetahuan dewan tentang anggaran, pemahaman dewan terhadap peraturan, prosedur dan kebijakan, serta pengawasan keuangan daerah.

Metode penyebaran kuesioner adalah Personally Administered Questionaires, yaitu penggunaan kuesioner yang disampaikan dan dikumpulkan oleh peneliti dengan menemui responden secara langsungan atau melalui kesekratariatan DPRD Propinsi Banten, sehingga peneliti dapat memberikan penjelasan seperlunya kepada responden mengenai hal-hal yang belum dimengerti oleh responden.

\section{HASIL DAN PEMBAHASAN Statistik Deskriptif}

Bagian ini akan memberikan informasi karateristik data yang digunakan dalam penelitian ini yang menginformasikan tentang: rata-rata, maksismum, minimum dan standara Deviasi dari data yang digunakan. Analisis deskriptif digunakan untuk memberikan gambaran atau deskripsi suatu data yang terlihat dari nilai ratarata (mean), standar deviasi, varian, minimum, maksimum, sum, range, kurtosis, dan skewness (Ghozali, 2016). 
Jurnal Administrasi Negara

ISSN : 2598-4039 (Online)

ISSN : 2302-2231 (Print)
Rudi Zulfikar, Kurniasih Dwi Astuti Jurusan Akuntansi

Universitas Sultan Ageng Tirtayasa

Tabel 1

Statistik Desktiptif

\begin{tabular}{|c|c|c|c|c|c|c|c|}
\hline \multirow{2}{*}{$\begin{array}{l}\text { Statistik } \\
\text { Deskriptif }\end{array}$} & \multirow{2}{*}{\multicolumn{2}{|c|}{$\begin{array}{c}\mathbf{N} \\
\text { Statistic }\end{array}$}} & \multirow{2}{*}{$\begin{array}{c}\text { Minimum } \\
\text { Statistic }\end{array}$} & \multirow{2}{*}{$\begin{array}{c}\text { Maximum } \\
\text { Statistic }\end{array}$} & \multicolumn{2}{|c|}{ Mean } & \multirow{2}{*}{$\begin{array}{l}\text { Std. Deviation } \\
\text { Statistic }\end{array}$} \\
\hline & & & & & Statistic & Std. Error & \\
\hline TK & & 5 & 0,00 & 0,38 & 0,102 & 0,00794 & 0,06733 \\
\hline KA & & 5 & 0,00 & 1,00 & 1,00 & 0,13700 & 1,16247 \\
\hline Per & & 85 & 0,10 & 0,650 & 0,420 & 0,81293 & 6,89797 \\
\hline Pol & & 85 & 0,09 & 0,770 & 0,770 & 0,10010 & 0,84939 \\
\hline Pen & & 85 & 0,07 & 0,95 & 0,8407 & 0,00534 & 0,04533 \\
\hline Pem & & 85 & 0,100 & 0,920 & 0,760 & 0,03864 & 0,32785 \\
\hline $\begin{array}{l}\text { Valid } \\
\text { (listwise) }\end{array}$ & v & 85 & & & & & \\
\hline
\end{tabular}

Berdasarkan tabel 5.1 dibawah ini menunjukkan bahwa rata - rata nilai Tingkat Korupsi (TK) setiap tahun sebesar 10,2\% di Pemerintah Propinsi Banten dengan nilai tertinggi sebesar $38 \%$ tahun 2010. Hal ini berarti bahwa Tingkat Korupsi di Pemerintah Propinsi Banten tergolong tinggi.

Kualitas Audit (KA) di Pemerintsh Propinsi Bnten memiliki nilai rata-rata 1,00 dengan nilai tertinggi 1,00 yaitu pada tahun 2016-2018. Kualitas Audit yang diperoleh atas Laporan Keuangan yaitu diberikan opini oleh Badan Pemeriksa Keuangan (BPK) Wajar Tanpa Pengecualian (WTP).

Personal Background (Per) memiliki nilai rata-rata sebesar $42 \%$ dengan nilai tertinggi tahun 2017 sebesar 65\% anggota DPRD yaitu Lakilaki. Sedangkan nilai terkecil tahun 2015 yaitu sebesar $10 \%$ yaitu Jumlah anggota DPRD Wanita.
Di Propinsi Banten, Anggota DPRD yang memiliki pengalaman politik (Politik Background) rata rata sebesar 77\% dengan tahun 2016 paling banyak anggota DPRD yang memiliki pengalaman politik sebelumnya yaitu sebesar 77\%. Sedangkan tahun 2018 sebesar 9\% anggota DPRD Propinsi Banten yang memiliki pengalaman.

Rata-rata Tingkat Pengetahuan (Pen) setiap anggota DPRD Banten Berkaitan dengan anggaran, sebesar $84,07 \%$ dengan rata-rata terbesar tahun 2015 sebesar 95\%. Sementara itu tahun 2017 memiliki nilai rata-rata sebesar 7\%. Kecilnya pengetahuan anggota DPRD tersebut berimplikasi terhadap hasil opini Badan Pemeriksa Keuangan (BPK) terhadap laporan keuangan Pemerintah Propinsi Banten dengan opini Pendapat tidak Wajar. Hal ini disebabkan kurangnya pemahaman anggota DPRD mengenai proses penyusunan dan pengawsaan realisasi anggaran. 
Jurnal Administrasi Negara

ISSN : 2598-4039 (Online)

ISSN : 2302-2231 (Print)
Rudi Zulfikar, Kurniasih Dwi Astuti Jurusan Akuntansi

Universitas Sultan Ageng Tirtayasa
Pemahaman (Pem) anggota DPRD Propinsi Banten dengan nilai rata-rata sebesar $76 \%$ artinya setiap anggota DPRD memiliki pemahman tentang peraturan dalam proses organisasi DPRD Banten. Nilai terkecil pada tahun 2017 sebesar 10\%. Sedangkan nilai rata-rata terbesar pada tahun 2016 sebsar 92\%.

\section{Hasil Pengujian Hipotesis}

Uji goodness of fit merupakan pengujan kecocokan atau kebaikan sesuai antara hasil pengamatan (frekuensi pengamatan) tertentu dengan frekuensi yang diperoleh berdasarkan nilai harapannya (frekuensi teroritis). Adapaun indikator dari goodness of fit dapat dilihat dari koefisien determinasinya (Adjusted RSquare). Hasil uji koefisien determinasi dapat dilihat pada tabel 2 berikut :

Tabel 2

Hasil Pengujian

\begin{tabular}{lcccc}
\hline Variabel & $\begin{array}{c}\text { Koefesien } \\
\text { Regresi }\end{array}$ & t hitung & Sig & \\
\hline (Constant) & $-0,153$ & $-0,777$ & 0,440 & \\
Per & $-0,003$ & $-2,849$ & 0,006 & $*)$ \\
Pol & 0,004 & 0,406 & 0,686 & \\
Pen & $-0,308$ & 1,837 & 0,071 & $*)$ \\
Pem & 0,337 & 1,23 & 0,002 & $* *)$ \\
\hline R Square & 0,178 & & \\
Adjusted $R$ & 0,221 & & \\
Square & & & & \\
F & 1,5736 & & & \\
Sig & 0,000 & & & \\
\hline ***) signifikan pada $\alpha=1 \%=0,01$ & & & \\
**) signifikan pada $\alpha=5 \%=0,05$ & & & \\
$*$ *) signifikan pada $\alpha=10 \%=0,1$ & & &
\end{tabular}

Berdasarkan tabel 2 menunjukkan bahwa koefisien determinasi yang menunjukkan nilai adjusted R2 sebesar 0,221. Hal ini berarti menunjukan bahwa variabel DA sebesar 22,10 \% dapat dijelaskan oleh KA, Per, Pol, Pen dan Pem sedangkan selebihnya variabel lain. Selanjutnya, Berdasarkan uji ANOVA diperoleh nilai $F$ Hitung sebesar 1,5736 dengan signifikansi 0,00. Hal ini dapat dikatakan bahwa model regresi ini dapat digunakan untuk mengestimasi Tingkat Korupsi. Jadi dapat disimpulkan bahwa karakteristik anggota Dewan Perwakilan Rakyat 
Jurnal Administrasi Negara

ISSN : 2598-4039 (Online)

ISSN : 2302-2231 (Print)

\section{Rudi Zulfikar, Kurniasih Dwi Astuti Jurusan Akuntansi}

Universitas Sultan Ageng Tirtayasa
Daerah sebagai variabel anteseden Tingkat Korupsi di Provinsi Banten.

Hasil pengujian koefisien regresi (uji t) dilakukan untuk mengetahui pengaruh satu variabel independen secara individual dalam menerangkan variasi variabel dependen dengan menganggap variabel independen lainnya bernilai tetap. Hasil pengujian yang dilakukan menunjukkan adanya pengaruh negatif Personal Background terhadap Tingkat Korupsi. Pengujian ini menunjukkan koefisien $\beta 1$ sebesar 0,003 dengan tingkat signifikansi (Qvalue) yang bernilai 0,006 di bawah tingkat signifikansi 0,05. Dengan demikian membuktikan terdapat pengaruh negatife Personal Background terhadap Tingkat Korupsi. Ini berarti hipotesis 1 (H1) didukung.

Personal background berkaitan erat dengan kualitas sumber daya manusia. Sumber daya manusia yang semakin berkualitas akan mampu memberikan kontribusi secara optimal dalam upaya pencapaian tujuan organisasi (Winarna, 2007). Semakin anggota DPRD memiliki personal background yang tinggi maka pengawasan yang dilakukannya juga semakin maksimal. Setiap lembaga (DPRD) memiliki political background seperti individu yang ada didalamnya. Karakteristik utama dari political background adalah terkait dengan nilai. Nilai merupakan prinsip dasar yang dijadikan sebagai pedoman hidup individu, dengan kata lain political background merupakan pedoman bagi anggota DPRD dalam menjalankan perannya khususnya yaitu pengawasan eksekutif. Sesuai dengan penelitian Witono dan Baswir (2003) yang memberikan bukti bahwa political background memiliki pengaruh negatif terhadap Tingkat Korupsi. Hal ini membuktikan adanya peran untuk menjalankan fungsi anggota DPRD.

DPRD akan dapat memainkan peranannya dengan baik apabila pimpinan dan anggota-anggotanya berada dalam kualifikasi ideal dalam arti memahami benar hak, tugas dan wewenangnya dan mampu mengaplikasikannya secara baik, dan didukung dengan pengalaman di bidang politik dan pemerintahan yang baik (Yudoyono, 2000).

Hipotesis adanya pengaruh positif Political Background terhadap Tingkat Korupsi tidak didukung oleh hasil pengujian. Pengujian ini menyimpulkan koefisien $\beta 2$ sebesar 0,004 dengan tingkat signifikansi (@value) 0,686 diatas tingkat signifikansi 0,05 . Dengan demikian hipotesis $2(\mathrm{H} 2)$ ditolak. Saat menjalankan tugasnya, anggota DPRD diharuskan untuk mematuhi aturan kerja yang telah ditetapkan sesuai komisi masingmasing,sehingga dengan latar belakang politik pada jabatan tertentu setiap individu yang berbeda tersebut, menyebabkan terjadinya perbedaan. Penelitian ini sesuai dengan Kartikasari (2012) membuktikan bahwa Political 
Jurnal Administrasi Negara

ISSN : 2598-4039 (Online)

ISSN : 2302-2231 (Print)

\section{Rudi Zulfikar, Kurniasih Dwi Astuti Jurusan Akuntansi}

Universitas Sultan Ageng Tirtayasa background berpengaruh positif terhadap tingkat korupsi.

Hasil pengujian yang dilakukan menunjukkan adanya pengaruh negatif pengetahuan anggota DPRD terhadap Tingkat Korupsi. Pengujian ini menunjukkan koefisien $\beta 3$ sebesar 0,308 dengan tingkat signifikansi (Qvalue) yang bernilai 0,071 di bawah tingkat signifikansi 0,05. Dengan demikian membuktikan terdapat pengaruh negatif Pengetahuan terhadap Tingkat Korupsi. Ini berarti hipotesis 3 (H3) didukung.

Pengetahuan merupakan persepsi responden tentang anggaran (RAPBD/APBD) dan deteksi terhadap pemborosan atau kegagalan, dan kebocoran anggaran. Sedangkan Nur dan Bambang (1999) menyebutkan bahwa pengetahuan pada dasarnya merupakan hasil dari proses melihat, mendengar, merasa dan berpikir yang menjadi dasar manusia dalam bersikap dan bertindak. Pengalaman dan pengetahuan yang tinggi akan sangat membantu seseorang dalam memecahkan persoalan yang dihadapinya sesuai dengan kedudukan anggota DPRD Sebagai wakil rakyat. Semakin luas pengetahuan anggota dewan tentang anggaran maka semakin besar kapabilitas anggota dewan tersebut dalam melakukan pengawasan sehingga dapat menurunkan tingkat korupsi. Sehingga dapat dirumuskan bahwa pengetahuan anggota dewan tentang anggaran berpengaruh positif terhadap kapabilitas anggota DPRD dalam pengawasan keuangan daerah (APBD).

Penelitian ini sesuai dengan hasil Werimon (2005) menunjukkan bahwa pertama, terdapat hubungan yang positif signifikan antara variabel pengetahuan anggota DPRD terhadap Tingkat Korupsi. Hasil ini konsisten dengan penelitian Indriani dan Baswir (2003) mengenai pengaruh pengetahuan dan RPPs terhadap peranan DPRD dalam pengawasan keuangan daerah menyimpulkan bahwa pengetahuan tentang anggaran berpengaruh terhadap peranan DPRD dalam pengawasan keuangan daerah. Selain itu, Yudoyono (2000) juga menyatakan bahwa DPRD akan dapat memainkan peranannya dengan baik apabila pimpinan dan anggota-anggotanya berada dalam kualifikasi ideal, dalam arti memahami benar hak, tugas, dan wewenangnya dan mampu mengaplikasikannya secara baik, dan didukung dengan tingkat pendidikan dan pengalaman di bidang politik dan pemerintahan yang memadai.

Hipotesis adanya pengaruh positif Pemahaman terhadap Tingkat Korupsi tidak didukung oleh hasil pengujian. Pengujian ini menyimpulkan koefisien $\beta 4$ sebesar 0,337 dengan tingkat signifikansi (Q-value) 0,002 diatas tingkat signifikansi 0,05. Dengan demikian hipotesis 4 (H4) didukung. Pemahaman regulasi merupakan pemahaman anggota DPRD mengenai 
Jurnal Administrasi Negara

ISSN : 2598-4039 (Online)

ISSN : 2302-2231 (Print)
Rudi Zulfikar, Kurniasih Dwi Astuti Jurusan Akuntansi

Universitas Sultan Ageng Tirtayasa peraturan, prosedur, dan kebijakan tentang keuangan daerah. Oleh karena itu, setiap anggota DPRD harus memahami regulasi agar dapat memastikan keuangan daerah sudah ber- jalan sesuai tujuan dan peraturan yang telah ditetapkan.Penelitian yang dilakukan oleh Dewi, dkk (2011) dan Kartikasari (2012) menunjukkan bahwa pemahaman regulasi berpengaruh positif dan signifikan terhadap pengawasan keuangan daerah.

Tabel 3

Hasil Pengujian

(Model ke 2)

\begin{tabular}{lcrll}
\hline \multicolumn{1}{c}{ Variabel } & Koefesien Regresi & t hitung & \multicolumn{1}{c}{ Sig } \\
\hline (Constant) & 0,334 & 0,564 & 0,030 & \\
TK & $-0,032$ & 2,558 & 0,018 & $* *)$ \\
R Square & 0,103 & & & \\
Adjusted $R$ Square & 0,298 & & & \\
F & 11,737 & & & \\
Sig & 0,000 & & \\
\hline$* * *)$ signifikan pada $\alpha=1 \%=0,01$ & & \\
$\left.{ }^{* *}\right)$ signifikan pada $\alpha=5 \%=0,05$ & & \\
$\left.{ }^{*}\right)$ signifikan pada $\alpha=10 \%=0,1$ & & &
\end{tabular}

Berdasarkan tabel 3 menunjukkan bahwa koefisien determinasi yang menunjukkan nilai adjusted R2 sebesar 0,298. Hal ini berarti menunjukan bahwa variabel Kualitas Audit (KA) sebesar 29,8\% dapat dijelaskan oleh Tingkat Korupsi (TK) sedangkan selebihnya variabel lain. Selanjutnya, Berdasarkan uji ANOVA diperoleh nilai $\mathrm{F}$ Hitung sebesar 11,737 dengan signifikansi 0,000. Hal ini dapat dikatakan bahwa model regresi ini dapat digunakan untuk mengestimasi Kualitas Audit. Jadi dapat disimpulkan bahwa Kualitas Audit dapat dipengaruhi oleh Tingkat Korupsi di Provinsi Banten.
Hasil pengujian pada tabel 3 yang dilakukan menunjukkan adanya pengaruh negatif Tingkat Korupsi terhadap Kualitas Audit. Pengujian ini menunjukkan koefisien $\beta 5$ sebesar 0,032 dengan tingkat signifikansi (Qvalue) yang bernilai 0,018 di bawah tingkat signifikansi 0,05. Dengan demikian membuktikan terdapat pengaruh negatif Tingkat Korupsi terhadap Kualitas Audit. Ini berarti hipotesis 5 (H5) didukung.

BPK memeriksa laporan keuangan lembaga pemerintah dengan tujuan memberi opini atas kewajaran laporan keuangan. Menurut standar audit, ada empat jenis opini sesuai 
Jurnal Administrasi Negara

ISSN : 2598-4039 (Online)

ISSN : 2302-2231 (Print)
Rudi Zulfikar, Kurniasih Dwi Astuti
Jurusan Akuntansi

Universitas Sultan Ageng Tirtayasa dengan tingkat kewajarannya, yaitu Wajar Tanpa Pengecualian (WTP), Wajar Dengan Pengecualian (WDP), Tidak Wajar (TW), dan Tidak Memberikan Pendapat (TMP). Agar laporan keuangan memiliki keandalan dan dapat digunakan sebagai dasar pengambilan keputusan, maka harus disusun sesuai standar akuntansi.

Opini WTP diberikan jika dalam segala hal yang material, laporan keuangan sudah sesuai dengan standar akuntansi keuangan. Sedang WDP jika ada ketidaksesuaian yang material pada satu atau beberapa pos laporan keuangan, namun tidak mempengaruhi kewajarannya secara keseluruhan. Sementara, TW jika laporan keuangan mengandung salah saji yang sangat material atau sangat menyesatkan sehingga tidak menyajikan secara wajar. TMP atau disclaimer jika auditor dibatasi geraknya, tidak bisa mengumpulkan bukti audit dengan nilai sangat material sehingga kewajaran laporan keuangan diragukan. Dalam audit, auditor menghadapi keterbatasan yang timbul karena proses audit itu sendiri. Pada umumnya auditor melakukan audit secara sampling karena tidak mungkin memeriksa seluruh transaksi, apalagi pada perusahaan besar atau entitas pemerintah yang menggunakan anggaran besar. Diperlukan biaya besar dan waktu lama untuk memeriksa seluruh populasi. Manfaat informasi dalam laporan keuangan juga sia-sia (menjadi basi) jika waktu pemeriksaannya lama, sementara informasi dibutuhkan segera untuk pengambilan keputusan. sebagai konsekuensi metoda SAMPLING, audit menerapkan konsep materialitas. Auditor akan membuat suatu perhitungan untuk menentukan batasan suatu transaksi dinilai material. Makin besar volume keuangan yang diperiksa, maka batas materialitasnya makin besar.

\section{PENUTUP}

\section{Simpulan dan Saran}

Pembuktian yang dilakukan dalam peneltian ini menyimpulkan rata - rata nilai Tingkat Korupsi (TK) setiap tahun sebesar 10,2\% di Pemerintah Propinsi Banten. Hal ini berarti bahwa Tingkat Korupsi di Pemerintah Propinsi Banten masih tergolong rendah semenjak terjadinya perubahan kepemimpinan di tahun 2017.

Hasil pengujian hipotesis menunjukkan bahwa koefisien $\beta 5$ sebesar -0,032 dengan tingkat signifikansi (Q-value) yang bernilai 0,018 di bawah tingkat signifikansi 0,05. Dengan demikian membuktikan terdapat pengaruh negatif Tingkat Korupsi terhadap Kualitas Audit. Ini berarti hipotesis 5 (H5) didukung.

Hasil lainnya yaitu adanya pengaruh negatif Personal Background terhadap Tingkat Korupsi. Pengujian ini menunjukkan koefisien $\beta 1$ sebesar 0,003 dengan tingkat signifikansi (Q- 
Jurnal Administrasi Negara

ISSN : 2598-4039 (Online)

ISSN : 2302-2231 (Print)
Rudi Zulfikar, Kurniasih Dwi Astuti Jurusan Akuntansi

Universitas Sultan Ageng Tirtayasa value) yang bernilai 0,006 di bawah tingkat signifikansi 0,05. Dengan demikian membuktikan terdapat pengaruh negatife Personal Background terhadap Tingkat Korupsi. Ini berarti hipotesis 1 (H1) didukung. Selanjutnya, Pengujian Pengetahuan anggota DPRD menunjukkan koefisien $\beta 3$ sebesar 0,308 dengan tingkat signifikansi (Qvalue) yang bernilai $0,071 \mathrm{di}$ bawah tingkat signifikansi 0,05. Dengan demikian membuktikan terdapat pengaruh negatif Pengetahuan anggota DPRD terhadap Tingkat Korupsi. Ini berarti hipotesis 3 (H3) didukung. Pembuktian lainnya, pengaruh positif Pemahaman terhadap Tingkat Korupsi didukung oleh hasil pengujian. Pengujian ini menyimpulkan koefisien $\beta 4$ sebesar 0,337 dengan tingkat signifikansi (Q-value) 0,002 diatas tingkat signifikansi 0,05. Dengan demikian hipotesis 4 (H4) didukung.

Penggunaan variable alternatif yang digunakan untuk membuktikan tentang komitmen organisasi sebagai anggota DPRD dalam menjalankan fungsinya. Selain itu melakukan pengujian tambahan dengan menggunakan Robust test yang didasarkan Split sampling setiap anggota partai. Sehingga akan dapat diperoleh informasi tentang anggota partai yang optimal melakukan fungsinya

\section{REFERENSI}

Andersson, S., \& Bergman, T. (2009). Controlling corruption in the public sector. Scandinavian Political Studies, 32(1), 45-70.

Ahmed, N. (2001). Development and working of parliaments in South Asia. Asian Journal of Political Science, 9(1), 18-48.

Afridi, F., Iversen, V., \& Sharan, M. R. (2017). Women political leaders, corruption, and learning: Evidence from a large public program in India. Economic Development and Cultural Change, 66(1), 1-30.

Biryukov, S. V. (2019). Uzbekistan as a Mirror of Change in Central Asia: A Sultanistic Regime and Its Transformation. Asian Survey, 59(2), 337-359.

Gustavson, M. (2015). Does good auditing generate quality of government?

Ghozali, I. (2006). Aplikasi analisis multivariate dengan program SPSS.

Forum for Corporate Governance Indonesia. (2002). Peran Dewan Komisaris dan Komite Audit dalam Pelaksanaan Corporate Governance. 
Hendrawan, A., Yulianeu, A., \& Cahyandi, K. (2018). Pengaruh Komptensi Terhadap Kinerja Tim. Journal of Management Review, 2(1), 143-150.

He, K., Pan, X., \& Tian, G. G. (2017). Political connections, audit opinions, and auditor choice: Evidence from the ouster of government officers. Auditing: A Journal of Practice \& Theory, 36(3), 91-114.

Kartikasari, D. (2012). Pengaruh Personal background, Political background, pemahaman regulasi terhadap peran anggota DPRD dalam pengawasan keuangan daerah (studi kasus pada DPRD Kabupaten Boyolali). Accounting Analysis Journal, 1(1).

Kassem, R., \& Higson, A. W. (2016). External auditors and corporate corruption: Implications for external audit regulators. Current Issues in Auditing, 10(1), P1-P10.

La Palombara, J. (Ed.). (2015). Bureaucracy and Political Development. (SPD-2) (Vol. 2). Princeton University Press.

Martin, S., \& Whitaker, R. (2019). Beyond committees: parliamentary oversight of coalition government in Britain. West European Politics, 1-23.

Malagueño, R., Albrecht, C., Ainge, C., \& Stephens, N. (2010). Accounting and corruption: a cross-country analysis. Journal of Money Laundering Control, 13(4), 372-393.

Mauro, P. 1995. 'Corruption and Growth', Quarterly Journal of Economics 110, 681-712.

Norton, P., \& Ahmed, N. (1998). Legislatures in Asia: exploring diversity. The Journal of Legislative Studies, 4(4), 1-12.

McMann, K. M., Pemstein, D., Seim, B., Teorell, J., \& Lindberg, S. I. (2016). Strategies of validation: Assessing the varieties of democracy corruption data. V-Dem Working Paper, 23.

Prabowo, H. Y., \& Cooper, K. (2016). Reunderstanding corruption in the Indonesian public sector through three behavioral lenses. Journal of Financial Crime, 23(4), 1028-1062.

Prihatini, E. S. (2019). Women who win in Indonesia: The impact of age, experience, and list position. In Women's Studies International Forum (Vol. 72, pp. 40-46). Pergamon. 
Rudi Zulfikar, Kurniasih Dwi Astuti Jurusan Akuntansi

ISSN : 2598-4039 (Online)

ISSN : 2302-2231 (Print)
Rocabert, J., Schimmelfennig, F., Crasnic, L., \& Winzen, T. (2019). The rise of international parliamentary institutions: Purpose and legitimation. The Review of International Organizations, 14(4), 607-631.

Rose-Ackerman, P. S. (2017). Political corruption and reform in democracies: theoretical perspectives. In Comparing political corruption and clientelism (pp. 65-82). Routledge.

Rose-Ackerman, S., \& Palifka, B. J. (2016). Corruption and government: Causes, consequences, and reform. Cambridge university press.

Republik Indonesia. 2004.UndangUndang Nomor 32Tahun 2004 tentang Pemerintah Daerah.

2004.Undang-Undang Nomor 33Tahun 2004 tentang Pemerintah Daerah.

2009.Undang-Undang Nomor 27Tahun 2009 tentang Majelis PermusyawaratanRakyat, Dewan perwakilan

Rakyat,
DewanPerwakilan Daerah, dan Dewan Perwakilan Rakyat Daerah.

Witono, B., \& Baswir, R. (2003). An Analysis on Influence of Personal Background and Political Culture on Regional Parliament's Role in Regional Financial Oversight: Analisis Pengaruh Personal Background dan Political Culture terhadap $\mathrm{P}$ eran DPRD dalam. Sosiohumanika (Vol. 16/A), 16(2003).

Winarna, J., \& Murni, S. (2007). Pengaruh personal background, political background dan pengetahuan dewan tentang anggaran terhadap peran DPRD dalam pengawasan keuangan daerah (Studi Kasus Di Karesidenan Surakarta dan Daerah Istimewa Yogyakarta Tahun 2006). Jurnal Bisnis dan Akuntansi, 9(2), 136-152.

Zyglidopoulos, S., Hirsch, P., Martin de Holan, P., \& Phillips, N. (2017). Expanding research on corporate corruption, management, and organizations. 